\title{
Expatriate TESOL Teachers' Perception of Professionalism: A Study in Saudi Context
}

\author{
Hamid Ali Khan Eusafzai \\ University of Central Asia, Naryn, Kyrgyz Republic
}

\begin{abstract}
Within the teaching field, the concept of professionalism has recently become controversial. Neoliberalism has eroded the traditional meanings of teachers' professionalism and teachers are grappling with an uncertain situation regarding their professional status. To end the uncertainty and resolve the controversial nature of the concept, approaching professionalism from teachers' own perspectives has been advocated. The current study, using a qualitative research methodology, explores teachers' perceptions of the concept and nature of professionalism. The study discovered that teachers clearly regard themselves and their profession as a classic profession and of great service to the society and this perception also guides their approach to their routine work.
\end{abstract}

Index Terms - teachers, perceptions, professionalism, TESOL, neo-liberalism, Saudi

\section{INTRODUCTION}

Professionalism, as an institution, was a source of social equilibrium. The institution, due to its social virtues, gradually evolved as an ideology (Evetts, 2012). The nature of this ideology changed with the passage of time, and in the present times, the ideology has become a source of discord among various social factions (Sachs, 2001) mainly due to conflicting interpretations and use. The process resulted in complicating the entire concept of professionalism and in an obliteration of consensual meaning of the concept. Teachers, being an integral and important segment of the society were also embroiled in this discord. Governments in different parts of the world tried to interpret professionalism for teachers in neo-liberal terms, and teachers found themselves compelled to adopt these meanings through various instruments of imposition. The governments' initiatives meant a whole new approach to teachers' work and a new form of identity- an identity which was essentially in clash with already existing identities of teachers as autonomous education experts. This clash is an example of the discord mentioned above. This discord resulted in obscuring the very meanings of teachers' professionalism. Thus, when we endeavour to search literature for meanings of teachers' professionalism, we find a great deal of polarization (Stronach, Corbin, Mcnamara, Stark, \& Warne, 2010) and a lack of clearly and universally defined meanings of teachers' professionalism as well. The ambiguity of the meanings aggravates as we discover that the polarization is mainly caused by a debate about teachers' professionalism among academicians trying to represent teachers' voice, and that teachers own perspective is lacking in the whole issue. Another factor, which is noticeable in literature, is that the issues and the debate related to the meanings of teachers' professionalism are grounded in the political, social and economic circumstances of the specific context of certain countries, and whatever little representation of teachers' perspective is there emanates from the context and the issues limited to this context. Therefore, to assign clear and universal meanings to the concept of teachers' professionalism, we need to ground the debate in the teachers' perspectives from diverse contexts. This study is one such attempt. It tried to discover expatriate TESOL teachers' perspective on the meanings of professionalism in Saudi Arabian context. The stance taken in this study is based on the approach of Evans (2008) who believes that professionalism is people's attitudinal and behavioural approach to their profession and that professionalism is a sum of individual professional culture of every member of an occupational or professional group.

\section{COMPLEXITY OF TEACHERS' PROFESSIONALISM}

The meanings of professionalism, in simplistic terms, are understood as "a set of valued qualities and dispositions" (Sykes, 1999, p.227). Generally, in mundane life, we refer to a professional or unprofessional individual if the individual possesses or lacks in possessing certain qualities and an approved job-related behaviour. The initial understanding of the concept of professionalism was based on the professionalization model of traditional professions of law and medicine. The model helps explain the trilateral relationship of the society, occupational groups and practitioners (Evetts, 2012). Here, in this model of professionalism, the triad existed in a perfect symbiotic relationship of quid pro quo among themselves (Evetts, 2009b). The principles guiding this relationship are altruism, expertise, social service, democracy, interdependence, ethics, trust and autonomy (Evetts, 2003b). The state or society grants special social and monetary privileges to the practitioners for their altruistic, specialized, and trusted service and ethical conduct. The practitioners are allowed to form occupational communities. These democratically formed communities enjoy considerable regulatory powers in terms of regulating the conduct and behavior of its members and also 
controlling entry into the profession (Evetts, 2009a). The practitioners and their communities of practice, in this model, are in an ideal and socially beneficial role and thus reaping the socially granted benefits. The whole social status of the occupational groups and practitioners appears worth aspiring for due to its socially benevolent and privileged role and thus has evolved into an ideology (Evetts, 2009b). The model has been praised for being a perfect representation and a "mode of social coordination" of work (Gewirtz, Mahony, Hextall, \& Cribb, 2009, p.4), a collegial "disciplinary mechanism" (Evetts, 2003, p.24), "a distinctive form of decentralized occupational control” (Evetts, 2006, p.136), and deemed vital to "social order and stability" (Evetts, 2012, p.8) of the society.

Alternatively, the straight forward ideology or concept of professionalism when related to teachers' work lives poses an evident complexity in terms of its meanings (Hilferty, 2008). The complexity can be attributed to the politicised use of the concept as an ideology, a belief system, a discourse and a rhetoric (Evetts, 2003a). The politicisation results from the fact that the concept has been applied and interpreted by different stakeholders from their own vantage point (Hilferty, 2008). The politicised use of the concept divests it of a simple solitary meaning (Goodson \& Hargreaves, 1996), and while endeavouring to understand what teachers' professionalism means, we are confronted by 'paradoxes and contradictions' (Evetts, 2006, p.135), 'inconsistent and incomplete usages' (Evans, 2008, p.2), and 'competing views about the nature of teacher professionalism' (Sachs, 2001, p.149). Therefore, any effort to discover a consensual definition of teachers' professionalism, results in discovering antithetical stances, meanings and explanations of the concept.

A survey of literature on teachers' professionalism reveals the polarization is rooted in certain issues affecting the professional lives of teachers. The issues are rooted in the social, economic and political conditions of certain societies. These conditions have stimulated certain changes in the working lives of teachers and are also responsible for creating the polarization which in turn has led to the complexity and obfuscation of the concept of teachers' professionalism (Sachs, 2001). These conditions have been described as outfalls of the neo liberal economic reforms and policies (Robertson, 1996). The main feature of these reforms and policies has been the "incorporation and marketization" of service and work (Shain \& Gleeson, 1999, p.449) of the previously autonomous professionals. Some of the epithets associated with these reforms and policies are: enterprise, commodification, competition, commercialization, privatization and deregulation. A whole set of values associated with free market ideology is embedded in these epithets. Traditional societal values like fair and equal chance, altruism, collectivism, egalitarian spirit and larger communal benefit have no place in this free market economy (Barnett, 2010). Apart from other "societal and systematic change(s)" (Evans, 2011, p.852), these reforms and policies have also affected education as the "neo-liberal rationalism [introduced] free-market principles into the field of education." (Hilferty, 2008, p. 163). These free market principles were introduced in education through the mechanism of managerialism (Bourke, Lidstone, \& Ryan, 2013, p.2). The principles underlying this form of management were those of the industrial management system. As a result of free market principals and the introduction of managerialism "education became redefined as an industry with inputs and outputs, operating as a .... market in which choices and competition would enhance the quality of teaching." (Bourke et al., 2013)

The principles of neo-liberal marketization were implemented in education by the state (Evans, 2011). The objective of the neo-liberal education reformation agenda (through the principles of free market competition) was to provide opportunity to the public to "have the freedom to seek better teaching and stronger education" (Holland, 2004 cited in Zeichner, 2010, p.1544). As teachers are the producers (using neo-liberal term) of education, thus the main thrust of the reforms was directed towards reformulating the way teachers worked (Evans, 2011). The aim of reformulation was to align the work of the teachers to the free-market culture of neo liberalism, by enhancing the quality of their product that is education in this case (Beck, 2008). The instrument of the reformulation was controlling the work of the teachers through managers and organizational standards of performance (Evetts, 2009b). The tools of the managerial form of control are stated to be subjecting teachers to the regimes of audit, accountability and surveillance (Evetts, 2012). The reformulation was done in the name of modernizing (Storey, 2007) the work of the teachers and the education system to meet the changing economic demands of a globalized world (Sachs, 2001).

The reformulation of teachers' work also meant the reformulation of teachers' social and professional status (Bourke et al., 2013) as occupational status is probably a statement of social status as well. Industrial is associated with workers and standard mechanical way of working. Industrialisation of education on the principles of free market, dealing with education as a product and teachers as producers of the product, specifying standard procedures for pedagogical practices similar to the mechanical procedures of the factory workers, all these mean reducing the status of a teacher from the traditional intellectual education expert to a mere "education worker" (Bourke et al., 2013, p.3). The loss of expert status implies the loss of autonomy and trust which teachers traditionally enjoyed and which also distinguished them from 'other workers' and their work from 'any work' in the society (Swann, McIntyre, Pell, Hargreaves, \& Cunningham, 2010). Traditionally, teachers had the privilege of and were considered capable of autonomous "classroom decisions-making" (Day, 1999, p.5); however, with the reformulated and necessarily diminished status, they were deprived of the privilege and were required to comply with the procedures which were imposed externally by the state through managerialism. Further, if teachers needed to involve in any pedagogical decision making, they could do it only "within the limits set by the state" (Gewirtz, Mahony, Hextall, \& Cribb, 2009, p.7). Such reformulation of the procedures of teachers' work and professional status, which has been termed as "the technicization of teaching" (Day, 
1999, p.10) and "proletarianization" (Evans, 2011, p.852), meant teachers adopting new social and occupational role, relationship and identity. They have to adopt a new set of values which was based on the free market principles of "competition and performance" rather than on the principles of "professional judgement and cooperation" (Bourke et al., 2013). They have to redefine and reconstitute the nature of their relationship with students, parents, colleagues, supervisors and the state (Shain \& Gleeson, 1999). Simply stated, teachers have to adopt the whole new meanings of what it implies to be a teacher and also of teaching.

How is all this related to the meanings of teachers' professionalism? Fundamentally, the reformulation of the meanings of teacher and teaching by the state on the principles of free market economy and the meanings attached to these by the teachers themselves are in conflict with each other. It is a conflict between what Bourke et al. (2013, p.121) terms as "emergent" and "residual" elements, and a dominant force (state in this case) trying to "promote and entrench the influence of certain 'emergent' elements... and "represent[ing] [state's] agenda of change as the necessary 'path to the future"'. The teachers' traditional concept of professionalism can be taken as a residual element and the state's new version of the concept of professionalism as the emergent element, and state being the dominant force feels mandated to reconstitute the professionalism of teachers and promote this reconstitution as an effort to prepare education enterprise to meet the new challenges. However, as professionalism is "about people's being" (Evans, 2011, p.855) and the emergent elements of the state defined professionalism are meddling with this being of teaches through the instruments of managerialism, technicization, and proletarianization, there appears to be a sort of "militancy" (Bourke et al., 2013, p.123) among teachers against this meddling. The state initiatives are promoted by the state as "new professionalism" (D. Hargreaves, 1994) and "professionalization" (Whitty, 2000) of teaching, whereas teachers consider them as "deprofessionalization" (Goodson \& Hargreaves, 1996). The state defined professionalism cannot become a "reality" as the teachers are not enacting it (Evans, 2011, p.862), and the teachers cannot enact their traditional professionalism because it is being eroded through reforms and power by the state as a residual from the past, hence unable to meet the challenges of the future. The friction between the emergent meanings and the residual meanings creates a complexity which hinders constituting any consensual and universal meanings of the concept of teachers' professionalism.

The friction between the state and teachers' professional community is also clearly reflected in the conceptualization of teachers' professionalism. We have conceptual approaches based on the premise that teachers' professional practices are "highly variable" (Talbert \& McLaughlin, 1994, p.127) and individualistic (Evans, 2008). These individual practices constitute the collective professionalism of the group. Thus, trying to define teachers' professionalism, we should take this aspect in view, and the definition ought to evolve from within these individual practices as any externally imposed definition will be unreal (Evans, 2008). Hence, based on this premise, we have conceptualizations of teachers' professionalism such as enacted professionalism ((Evans, 2011), professionalism from within (Evetts, 2012), and democratic professionalism (Sachs, 2001). All these conceptualizations try to define teachers' professionalism from teachers' vantage point and use individual practices of teachers as a predicate for explaining what teachers' professionalism means.

However, the proponents of the state's drive of teachers' professionalization take the variability and individuality arguments as a basis for championing the reformulation of teachers' professionalism by the state. They consider individuality as null professionalism (A. Hargreaves, 2000) and consider it as a ploy to protect teachers from change (D. Hargreaves, 1994). They associate values of collaboration, teamwork, mentoring, partnership, and empowerment to teachers' professionalism. They feel that teachers need to change from semi-professional status to professional status through the process of professionalization (Beck, 2008) and advocate that the new-liberal reforms are actually a route to teachers' professionalization and modernization. They advocate that teachers need to be mentored, engaged in extensive collaboration with colleagues through teamwork, and with parents and society through a mechanism of educational partnership (A. Hargreaves, 2000). They call teachers' professionalism emanating from this process of professionalization as new professionalism (Whitty, 2000). However, these approaches are dismissed by the proponents of the 'professionalism from within' as demanded professionalism (Evans, 2011) or 'organizational professionalism' (Evetts, 2012). New professionalism is considered by them as de-professionalization, mentoring as surveillance, teamwork as loss of autonomy, and partnership as exposure to market competition and collaboration as compliance.

The polarization resulting from efforts to conceptualize teachers' professionalism is basically a discourse of promotion, rejection and conservation. The proponents of the state's version of professionalism promote their preferred type of professionalism by making it appealing to the teachers and rejecting the traditional version of teachers' professionalism as obsolete. The proponents of teachers' preferred concept of professionalism reject the state's version, considering it as a threat to teachers' identity and use the discourse of rejection to conserve teachers' traditional identity. Therefore, in this friction of discourses the meanings of professionalism are divaricate and, in literature on teachers' professionalism, we find a lamentation about the lack of single and unified meanings of teachers' professionalism:

"what it means to be professional, to show professionalism or to pursue professionalization is not universally agreed or understood" (Goodson \& Hargreaves, 1996, p.4)

\section{Professionalism in My Personal Perspective}

The complexity of the concept and the need to have a universal meanings increases as I look at the whole notion of professionalism from my perspective. I perceive that the struggle on the meanings of teachers' professionalism is rooted 
in the social, political and economic circumstances unique to Anglosphere countries. Teachers in these countries face a whirlwind of education reforms (Robertson, 1996) which also included a redefinition of their professional role and identity. I approached the whole issue as an alien or an outsider to these circumstances. I find it difficult to identify with the challenges posed to the teachers by the drive of new professionalism or re-professionalization springing from neoliberal reforms initiated by the governments in these countries. My circumstances and challenges are different than the school teachers in the Anglosphere countries (Gewirtz et al., 2009), and I am not alone in my experice. Perhaps, thousands of teachers are enacting their own professionalism in a situation like mine. To build a perspective and to help juxtapose the two kinds of professional lives and challenges (lives of teachers in Anglosphere countries and of teachers in situations similar to mine), I would try to build my professional profile. The profile will hopefully give a glimpse of the circumstance I work in and may also highlight the challenges I face. Additionally, as mentioned earlier, the profile is, perhaps, also representative of the thousands of other teachers working in the same context.

As a teacher, I fall in the broader category of a non-native English speaking teacher. My initial "claim to professionalism" (that is, my status as a professional teacher) is my postgraduate degree, knowledge of the subject that I teach, "demonstrable practical competence" (Beck, 2008, p.125) and the "practical experience" (Goodson \& Hargreaves, 1996, p.5). I work on a renewable yearly contract in a higher education institute in Saudi Arabia. Prior to my contact with the literature on teachers' professionalism, I never thought of my status in terms of being professional or not professional. Teaching was an occupation adopted because of my academic qualification. The image of the teacher that I aspired to be was, and still is, that of a "benign and altruistic being serving society" (Parson, 1954 cited in Goodson \& Hargreaves, 1996, p.5), and this is also the kind of persona that my society expects from me as a teacher. I enjoy freedom inside my classroom and in my routine pedagogical practices. To successfully execute these routine professional practices, I depend on my experience and "professional judgment" (Whitty, 2000) not on any externally defined standards. The government interference in the job is absolutely minimal. The affairs of curriculum, syllabus and tests are locally managed with considerable input by the teachers. My professional status depends on the societal and supervisors' approval of regarding me as a professional. The society and the supervisors trust me with my expertise for the service I am providing. Credentials for my professional success come from my supervisors in the form of an annual renewal of my contract. Though fully professional in the local work context of my own country, I face deprofessionalization in the international ELT (English Language Teaching) market where native English speaking teachers are preferred and a bias against hiring non-native English speaking teachers exist (Watson Todd \& Pojanapunya, 2009). This bias threatens my professionalism and to meet the challenge I try to re-professionalize myself through professional development activities such as pursuing and achieving recognized academic specialism or training in ELT. Though, the academic specialisms further strengthens my position in my country as fully professional teacher, however, in the international commercial market of ELT, I only achieve the status of a "partially professionalized" teacher (Lortie, 1975 cited in Goodson \& Hargreaves, 1996, p.5), as I am only employed when native speaking teachers are not available to fill the position. My challenges of professionalization and de-professionalization are rooted in my status as a non-native teacher. However, I do not face a complexity of role and relationship as a result of these challenges. Professionalized or de-professionalized, my status and the challenges are also clear and stable. I do not face a crisis of identity as a result of emergent and residual paradigms of professionalism.

Based on this juxtaposition, I can say that the challenges faced by the teachers in Anglosphere countries perhaps do not reflect the kind of meanings and challenges which are relevant to the teachers working in my situation. Therefore, we can conclude that any debate and any emergence of meanings and challenges regarding teachers' professionalism in the Anglosphere countries lack universality. We need to widen the search for the meanings for teachers' professionalism to contexts outside Anglosphere countries. This inclusiveness may help us broaden the horizon on the issue of teachers' professionalism and may also help find a universal definition for it.

\section{RESEARCH FOCUS}

Apart from an inclusiveness of contextual diversity, we also need to be aware of the point that not only meanings of teachers' professionalism may be different from one context to another; these can also be different from one individual to another. We also need to be aware of the aspect that broader meanings are the sum of the individual meanings (Evans, 2008) and the individuals in this case of teachers' professionalism are the teachers themselves. Teachers should be the ones defining the meanings of their professionalism. However, the debate in the area of teachers' professionalism is mainly shaped by the "educational analysts" divided into two groups of pro and anti new professionalism of teachers (Storey, 2007). The teachers' perspective on the meanings of professionalism and their experiences are underrepresented in literature (Goodson \& Hargreaves, 1996). Therefore, there is a need not only to take the debate to the teachers themselves to find their perspective but also to "investigate individual realities at the local levels" (Day, 1999, p.11) as "teachers' work lives are heavily framed by local ...traditions and norms" (Talbert \& McLaughlin, 1994, p.127). This paper is one such attempt in the direction. It tries to find teachers perspectives on professionalism; their "mode of [professional] being"(Evans, 2011, p.855) based on the individual's perceptions and in a context outside the Anglosphere countries. The singular question leading the investigation is: How do teachers perceive their professionalism? 
As suggested by the research question the objective is to discover the "ideologically-, attitudinally-, intellectually-, and epistemologically-based stance" of this group of teachers (Evans, 2008, p.8) through mainly trying to frame answer to questions such as:

"what they do (in the context of their working lives); how and why they do it; what they know and understand; where and how they acquire their knowledge and understanding; what... attitudes they hold; what codes of behaviour they follow; what their function is; what purpose they perform; what quality of service they provide" (Evans, 2011, p.855)

For this research the focus of investigation will be on the attitudes, values and motivation, as I believe that they serve as a framework for our actions. Thus, I shall be trying to interpret through interviews teachers' perception about the status of teaching as a profession or otherwise, the role of the teachers, the values that frame their actions and the contextual elements that motivate or demotivate them.

\section{RESEARCH CONTEXT AND PARTICIPANTS}

The research has been conducted in the context of an English language centre of a higher education institution in Saudi Arabia. The centre is autonomous in status and runs its daily affairs locally. The standards for work practices are defined locally and mainly through the input from the working committees of the teachers. However, the scope and level of implementation of the standards and rules, and their interpretation remains the prerogative of the executive head of the centre. Then the change of the executive head means a whole new approach to the working of the centre and the running of the day to day affairs of the centre. Thus, there always remains vagueness and ambiguity when it comes to defining standards or rules. Teachers come from a diverse range of nationalities and educational background. The participants of the current research were expatriate teachers working in the centre. A total number of 16 purposivelyselected teachers participated in the research. There were 15 male and one female participants. The participants were from USA, England, Ethiopia, Senegal, Sudan, Jordan, Pakistan, Malaysia, Nigeria, Canada, Turkey, Philippines, and Ireland. The average age was 40 years and the average teaching experience was 14 years. To hide their actual identity, they are coded as T1, T2 ...T16 in the findings section.

\section{METHODOLOGY}

The research was conducted within interpretive framework. The standard data collection methodology of the interpretive framework is qualitative. For this research data was collected through semi-structured interviews. The open-ended interview questions were related to the concept of professionalism in general and of teachers' professionalism in particular. Data was analysed using the three stage protocol presented by Ary, Jacobs, Sorensen, \& Walker (2013). Standard ethical requirements of social sciences research were fulfilled.

\section{FINDINGS: TEACHERS’ PERCEPTIONS OF PROFESSIONALISM}

\section{A. Status of Teaching as a Profession}

Teaching is unequivocally regarded as a profession distinct from other jobs a by these teachers. The reasons for regarding teaching as a profession range from the simple reason of teaching being a source of income to its being a complex job requiring a set of knowledge, skills and dedication.

On a mundane level teaching is regarded as a work. It reflects teachers perceiving work and profession interchangeably.

“... as I have already mentioned for me it's a profession because I'm earning my bread and butter. ” (T4)

Teaching is also perceived as a career one dedicates himself to, and to be worth of the career, one needs to possess the virtues of commitment, knowledge and expertise.

“...teaching is a profession, I would say a profession similar to a career, it's a line, you call it a line of work that you dedicate yourself to, it requires a specific set of knowledge and skills,.... it's something not everyone can do..... I think possessing knowledge in a subject doesn't mean you have the ability to teach it...... I mean personally if you ask me what's more important subject knowledge or teaching ability, I would say teaching ability was more important....so I think it's a profession in a sense that you have to develop a set of skills..." (T16)

"...we do it for a living consistently and if you have some type of expertise in it that sure is a profession....." (T7)

Teaching as a profession is regarded as having a specialized nature based on the lifelong dedication, knowledge and skills required to teach, and the specialized nature also accords it the status of an exclusive community of practice open to only those who possess these elements.

“.....I believe teaching is a profession because it's something not everyone can do....it requires training or specialized knowledge or something sort of expertise” (T11)

Seemingly, teaching is assigned with the signature traits of the classic professions. The status of teaching as a profession is justified on the basis of teaching requiring a certain knowledge base, a certain set of skills and expertise, and additionally a personal investment of the teacher in the form of long term commitment and dedication. Moreover, the knowledge base and skills are considered complementary and the teachers have an understanding that knowledge will not be effective without skills. However, pedagogical skills and expertise are given precedence over the subject 
knowledge. Due to the importance of pedagogical skills as a prerequisite, teaching profession, in the perception of the teachers, attains the right to be an exclusive community of practice with restricted entry and a character different from other professions. The characteristics, thus attributed to teaching, also form the basis for perceiving teaching as a profession with a higher social prestige.

"It is a well-respected profession, similar to other white-collar professions in terms of benefits and work conditions." (T1)

\section{B. Status and Role of Teachers}

“...... whatever the teacher does can change somebody's life” (T 16)

“.... well the job of a doctor ends when he prescribes certain medicine to the patient but a teacher's job goes on because the way you become a role model for our students you give them something good which they would practice in their entire life, so the way you are inculcating the moral values, the knowledge you are giving them, it would make them ...good human beings..." (T10)

"I think teaching is a profession you should not do for money but because it's something noble, you have some goals.....like sharing knowledge and educating people." (T6)

Teachers have a strong notion of the social importance and special value of their role. Data analysis revealed that teachers perceive themselves as a source of change, a source of knowledge and moral values, and as human developers. They consider teaching a calling or a vocation. Teaching, on a lowly level, is a job and therefore a source of income, however as a calling, it is much more sublime and socially valuable. Society is human beings and a good society and a healthy social order is dependent on good human beings. Teachers play a significant social role as these knowledgeable, educated, skilled and morally sound human beings evolve in their classes as a result of their teaching. Hence, teachers believe in the nurturing aspect of teaching profession (Day, Kington, Stobart, \& Sammons, 2007), that is, nurturing students into the sound human beings of the future. The reason might be that most of the participants are career teachers working in non-commercial national institution, and an important aspect of all national educational institutions is to develop the human capital of the society not only economically but also socially and morally. Whereas, educational institutions embracing the neo-liberal philosophy of commercialized and commoditised education lay an emphasis on mere competencies and skills, the traditional philosophy of education contrarily lays stress on the human, moral and personality-developing aspects of education. As these teachers, probably, did not face neo-liberalism in their country or in their current context of work, thus they still believe in the traditional role of teacher and in its value for the society.

\section{Nature of Service and Values}

Teachers perceive their professional role socially valuable and benevolent and these aspects also inform both their perception of the nature of the professional service that they provide to the society, and also the values that guide their professional practices.

Hence, the service provided is a reflection of the role, and as the role of teachers is of social value so is the service. They serve their clients, which are students and indirectly the society itself, by transferring them not only knowledge, skills and competencies but also the ability to utilizing these for success in life, thus the underlying principle of the service is to develop the life-enabling capacities of the students.

"I suppose imparting knowledge is obviously the main thing in teaching and we have to be responsible for making sure that students are getting a lot of benefit from them" (T12)

"teachers are taking care of your future career, they are training you, they are taking care of your future plan, future objective, they put you on the right track, they show you how to be the right person in future, how to be the right asset for this world...." (T9)

The service is not limited to teaching their classes on a scheduled time and achieving curriculum standards for particular lessons. The service is to educate and enable students as learners.

“...my job is to help learners' wade through the learning process" (T5)

The job, or the service provided, is not limited to the walls of the classroom; it requires an involvement much beyond the physical locale of the classroom and the time that teachers need to spend within these walls. There is a perception of the challenging nature of the job, a job which demands a higher and consistent level of commitment.

"I mean it is a full time job, 24/7, even when you are on a vacation, you still thinking of what you wanna do with your students, there it's a full time job, it's a full time 24/7 profession not a job" (T10)

Teachers believe that the relationship of teacher and student is unique and this relationship gives teaching a distinct and special character.

"I think the quality of teaching is different because there is a very certain relationship between a teacher and students which may be is different between a doctor or his patient." (T15)

This relationship can perhaps be defined as a relationship of care and passion and here occurs an integration of personal and professional in teachers and lending an emotional quality to their work (Day, 2004).

"I think it's like parent, when you have a child you are the most responsible about that child as a teacher, I think a learner who comes to you, be it an adult or younger age, you are very responsible." (T3) 
As a result of care and passion for the learning of the students and their person, the students become a source of feedback validating the professionalism of the teachers as well as a source of what Hargreaves (1999) terms psychic rewards, and also a reason for setting values in dealing with the students and engaging in professional development.

"I think the feedback that I get from my students gives me that impression that I'm a professional person." (T8)

"I think if you feel and if you see that the one particular student has benefited from you after they finish the classes... then that's the most enjoyable part." (T4)

"...you treat students fairly and objectively, making sure you assess students fairly and objectively and then ....making sure you are up to speed with research and developments in the field making sure you do the best job." (T16)

Apparently, the teachers perceive professional development important to achieve quality in their work but they are also aware that to maintain this quality professional development should be an on-going process.

“...professional development makes you true profession which is otherwise improbable” (T9)

"Professional development is an on-going thing, so as teachers we never stop developing, if you stop developing as a teacher, you stop being a teacher." (T14)

The values underpinning the service that they provide are mostly intrinsic and springing from a strong sense of the moral and vocational nature of the profession that they are pursuing. Teachers perceive themselves as moral agents. Thus, they believe that teachers, to assume the position of a role model, must practice what they desire to inculcate in their student.

"Teachers are role models for impressionable youth. If a teacher is always on time, organized, efficient, honest, open-minded, dedicated, hardworking, and knowledgeable in his/her field, this can encourage students to have the same standards as students and later in their professional life." (T13)

The teachers have a realization that they are trusted as professionals and students' attitude towards them is based on a relationship of trust.

"Students consider you as a source of knowledge, they trust you, all these two aspects I talked about: honesty, dedication; so they believe these things are already there" (T7)

Thus, they perceive that teachers need to prove themselves worth of the trust through the way that they deliver their lessons.

"You need to take your lessons seriously, you need to prepare when you go into class, you need to deliver the best lesson, it doesn't have to be perfect every time." (T15)

Regarding the well-being and care of the students, we see an integration of the personal and the professional selves of the teacher, however, when it comes to prioritizing personal over profession, the teachers prefer the later and do not let the personal interfere with the professional.

“... as a professional, I do what is expected of me, for the sake of the students and my colleagues, behaving as someone who exhibit the highest standards of teaching and who doesn't let personal feelings interfere with his her ability to perform all tasks of the job." (T1)

Overall, we find an image of a teacher whose professional self is guided by intrinsic values of honesty, dedication and altruism. These values also emerge as a drive behind ensuring high standards of performance in teaching and in the job procedures related to the classroom activities. Thus, we have a quality conscious individual who maintains quality in service to the students through keeping his knowledge and skills updated.

\section{Teachers' sources of motivation}

Psychic rewards are the major source of teachers' motivation and satisfaction or dissatisfaction with their job. This finding is in line with what Lortie (1975, cited in A. Hargreaves, 1999) discovered in his study.

"It's satisfying when you feel that your efforts are gaining and your students are actually benefitting. The satisfaction you know in seeing your students' progress" (T13)

Autonomy is also a source of motivation. Teachers consider it a validation of their expertise when allowed to work autonomously and the sense of being autonomous feels rewarding.

"It's motivating if I am regarded as a professional, if for example my boss or my school allows me to do freely what I want to do based on what I am trained for." (T11)

However, the autonomy mentioned here is not the unbridled use of personal judgement. The autonomy or freedom to act is grounded in the professional training that a teacher has. Thus, it is perceived as a freedom of action regulated by professional judgement and discretion.

Another source of motivation is the participatory and collegial environment. If teachers are allowed to participate in management by seeking their opinion or advice, they consider it as recognition of their position as professionals in the job but it is also considered another source of validation of their expertise.

"I think when you are being consulted on matters, most probably when you most feel like a professional, when your professional knowledge is being sought, I think it's most probably when you most feel like a professional, makes you feel good, you know it's recognition, I did not just wanted to be a cog in a machine, I wanted to be someone who had a value.... Whose position was warranted and was valued by others, and I think that's what you feel when you are treated as a professional...... it's a validation and it's a recognition." (T16) 


\section{Cumulative IMAGE OF PROFESSIONALISM}

The cumulative image of professional subjectivities and selves or the concept of teachers' professionalism emerging from teachers' account of their perceptions is an idealistic concept of professionalism and appears to be rooted in the paradigm of professionalism associated with the classic professions like doctors and lawyers. Teaching is an esoteric profession as it requires a knowledge base, expertise through training and experience. It also requires a higher level of commitment and dedication. The work of teachers is of special value to the students and society as it is related to the future of both. Welfare and progress of the student is the nucleus of teachers' work, commitment and dedication. The work of the teacher is guided by intrinsic values of care, honesty, trust, and altruism and all these values are to be adhered to for the benefit of the learning of the student. Monetary benefits of the work of teachers are considered of secondary importance, and greater value is attached to the psychic rewards such as students' success and appreciation for work and service. Success of students and their gratitude is the standard whereby teachers can validate the level of their professionalism. Teachers' relation with the management is based on the principles of participation, mutual respect and collegiality. Managers are considered as facilitators of autonomy, participatory environment and opportunities of professional development.

The study, in the context of TESOL teachers' perception and understanding of professionalism, helped enhance my understanding of the meanings of professionalism. As I have mentioned earlier in this paper, being a TESOL teacher just meant a work for me, a work I was entitled to do due to my educational and professional qualifications or because I could do it. I never thought of my work in terms of profession and my attitude to my work in terms of professionalism. This was due to certain factors. One factor probably can be that TESOL education and training programs perhaps do not sensitize teachers to professionalism as an identity or as subjectivity. All such programs that I have attended mainly focus on lesson procedures leading to "the mental acquisition of language" (Johnston, 2003, p.1). Another factor is that TESOL teachers teaching in countries other than their own are considered as unprofessional temporary job seekers teaching not as an end in itself but "as a means to an end: to finance travel adventures, practice a foreign language, or put off finding a "real job"” (original emphasis) (Lorimer \& Schulte, 2012, p.32). Thus, the perception of TESOL teachers is perhaps more of temporary workers rather than professionals. However, this study helped realizing the professional subjectivity of the TESOL teachers and in a way also my own professional subjectivity. Although, the participants were from a range of nationalities, but there appears unanimity of perception regarding the professional being of the teachers, and it helps falsify certain notions about the professionalism of TESOL teachers. Teachers appear to possess stable professional beings with a long term commitment to their profession. They appear to believe in the educational and moral value of language teaching. For them language teaching is not just helping the students acquire proficiency in the target language but also to nurture and develop them socially and morally. Thus, TESOL teachers' who take teaching as a career, possess a strong sense of purpose and attribute special value to their work and this sense transcends national, contextual and cultural boundaries. They appear to possess a stable sense of professionalism based predominantly on the moral and futuristic purpose of teaching rather than the superficial and short term aim of developing target language proficiency among their students. They perceive their role as "emissaries of the life of the mind" (Strike, 1990, p.113) rather than mere performers of the rituals of lesson planning and instruments of target language content delivering.

\section{CONCLUSION}

The use of the concept of profession and professionalism as a rhetorical tool by various stakeholders to implement and achieve their agenda, and probably also to reject the agenda of others, resulted in a wrangle which rather than clarifying, muddled the very meanings of professionalism (Englund, 1996). It is also a fact that the main perpetrators involved in the wrangling are academicians rather than the professionals themselves. Same is true in the case of teachers' professionalism. For teachers, the meanings of their professionalism was defined by the government and also imposed on them by the government. The meaning was foreign to the professional selves of the teachers. Adopting the foreign meanings meant acculturation in a way as to obliterate the previous professional self and assume a self which was in discord with the very nature of the professional being of the teachers. Moreover, in the whole saga of wrangling on the meanings, the participation of the teachers and their viewpoint remained ignored and the whole debate was led by the academicians becoming the mouth piece for the teachers. Representing teachers view by others, in defining what is related to the very being of the teachers, is unrealistic and impractical. It exacerbated the very complexity and vagueness of the meaning of professionalism. The current research was to reduce the complexity and vagueness by seeking teachers' perspective on the meanings of professionalism, where professionalism means the inner quality of the work of the teachers (Englund, 1996). Additionally, the aim was also to broaden the perspective by investigation a context external to the Anglosphere countries. The research helped us discover the TESOL teachers' perceptions of the concept of professionalism working in an environment where their professional identity is not challenged by neoliberalism, and they are perceived to be teaching mainly for personal benefits rather than for altruistic purpose. We discovered that teachers' perception of their professionalism is rooted in idealistic and classic paradigm of professionalism. Teachers attached prestige and social value to their service. The finding probably also highlights that professionalization is a process mainly rooted in perceptions of the individuals rather than a kind of external process. 
Intrinsic professionalization emanating from the perceptions of the practitioners is perhaps more professionalizing than extrinsic professionalization especially if it is in clash with the teachers professional being. If in clash, it meddles with the being of the teacher in a negative way and leads to a chaos of identity.

\section{REFERENCES}

[1] Ary, D., Jacobs, L., Sorensen, C., \& Walker, D. (2013). Introduction to research in education. CA: Cengage Learning.

[2] Barnett, C. (2010). “Publics and markets. What's wrong with neoliberalism?'”. In J. P. Smith, Susan J.; Pain, Rachel; Marston, Sallie A. and Jones III (Ed.), The Sage Handbook of Social Geographies Eds SJ ... (pp. 269-296). London: Sage.

[3] Beck, J. (2008). Governmental professionalism: re-professionalising or de-professionalising teachers in England. British Journal of Educational Studies, 56(2), 119-143.

[4] Bourke, T., Lidstone, J., \& Ryan, M. (2013). Teachers performing professionalism: a Foucauldian archaeology. Sage Open, 3, $1-14$.

[5] Day, C. (1999). Being a teacher, developing as a professional. In Developing Teachers, the challenges of lifelong learning (pp. 1-21). London: Falmer Press.

[6] Day, C. (2004). A Passion for Teaching. Abingdon, UK: Taylor \& Francis. http://doi.org/10.4324/9780203464342.

[7] Day, C., Kington, A., Stobart, G., \& Sammons, P. (2007). The personal and professional selves of teachers: stable and unstable identities. British Educational Research Journal, 32(4), 601-616.

[8] Englund, T. (1996). Are professional teachers a good thing? In I. Goodson \& A. Hargreaves (Eds.), Teachers' Professional Lives (pp. 75-87). London, UK: Falmer Press.

[9] Evans, L. (2008). Professionalism, Professionality and the Development of Education Professionals. British Journal of Educational Studies, 56(1), 1-28.

[10] Evans, L. (2011). The "shape" of teacher professionalism in England: professional standards, performance management, professional development and the changes proposed in the 2010 White Paper. British Educational Research Journal, 37(5), $851-870$.

[11] Evetts, J. (2003a). The construction of professionalsim in new and existing occupational context: promoting and facilitating occupational change. International Journal of Sociology and Social Policy, 23(4/5), 22-35.

[12] Evetts, J. (2003b). The sociological analysis of professionalsim, occupational change in the modern world. International Sociology, 18(2), 395-415.

[13] Evetts, J. (2006). Short Note: the sociology of professional groups: new directions. Current Sociology, 54(1), 133-143. http://doi.org/10.1177/0011392106057161.

[14] Evetts, J. (2009a). New professionalism and new public management: changes, continuities and consequences. Comparative Sociology, 8, 247-266.

[15] Evetts, J. (2009b). The management of professionalism: a contemporary paradox. In S. Gewirtz, P. Mahony, I. Hextall, \& A. Cribb (Eds.), Changing Teacher Professionalism: International trends, challenges and ways forward (pp. 19-30). Oxon: Routledge.

[16] Evetts, J. (2012). Professionalism in turbulent times: changes, challenges and opportunities. In Propel International Conference (pp. 1-33). Stirling.

[17] Gewirtz, S., Mahony, P., Hextall, I., \& Cribb, A. (2009). Policy, professionalism and practice, understanding and enhancing teachers' work. In S. Gewirtz, P. Mahony, I. Hextall, \& A. Cribb (Eds.), Changing Teacher Professionalism: International trends, challenges and ways forward (pp. 3-16). Oxon: Routledge.

[18] Goodson, I., \& Hargreaves, A. (1996). Teachers' professional lives: aspirations and actualities. In I. Goodson \& A. Hargreaves (Eds.), Teachers' Professional Lives (pp. 1-27). London, UK: Falmer Press.

[19] Hargreaves, A. (1999). The Psychic Rewards (and annoyances) of Teaching. In M. Hamersley (Ed.), Researching School Experience, Ethnographic Studies of Teaching and Learning (pp. 85-103). London: Falmer Press.

[20] Hargreaves, A. (2000). Four ages of professionalism and professional learning. Teachers and Teaching: History and Practice, $6(2), 151-182$

[21] Hargreaves, D. (1994). The new professionalism: the synthesis of professional and institutional development. Teaching and Teacher Education, 10(4), 423-438.

[22] Hilferty, F. (2008). Theorising teacher professionalism as an enacted discourse of power. British Journal of Sociology of Education, 29(2), 161-173.

[23] Johnston, B. (2003). Values in English language teaching. London: Lawrence Erlbaum.

[24] Lorimer, C., \& Schulte, J. (2012). Reimagining TESOL professionalism: The graduate student perspective. The CATESOL Journal, 23(1), 31-44.

[25] Robertson, S. (1996). Teachers' work, restructuring and postfordism: constructing the new "professionalism.” In I. Goodson \& A. Hargreaves (Eds.), Teachers' Professional Lives (pp. 28-55). London, Uk: Falmer Press.

[26] Sachs, J. (2001). Teacher Professional identity: competing discourses, competing outcomes. Journal of Education Policy, 16(2), $149-161$.

[27] Shain, F., \& Gleeson, D. (1999). Under new management: changing conceptions of teacher professionalism policy in the further education sector. Journal of Education Policy, 14(4), 445-462.

[28] Storey, A. (2007). Cultural shifts in teaching: new workforce, new professionalism? Curriculum Journal, 18(3), $253-270$.

[29] Strike, K. (1990). Is teaching a profession: How would we know? Journal of Personal Evaluation in Education, 4(1), 91-117.

[30] Stronach, I., Corbin, B., Mcnamara, O., Stark, S., \& Warne, T. (2010). Towards an uncertain politics of professionalism $\square$ : teacher and nurse identities in flux. Jounal of Education Policy, 17(1), 109-138.

[31] Swann, M., McIntyre, J., Pell, T., Hargreaves, L., \& Cunningham, M. (2010). Teachers' conceptions of teacher professionalism in England 2003 and 2006. British Educational Research Journal, 36(4), 549-571. 
[32] Sykes, G. (1999). The "new professionalism" in education: an appraisal. In J. Murphy \& K. Louis (Eds.), Handbook of Research on Educational Administration (2nd ed., pp. 227-249). San Francisco: Jossey-Bass.

[33] Talbert, J., \& McLaughlin, M. (1994). Teacher professionalism in local school contexts. American Journal of Education, $102(2), 123-153$

[34] Watson Todd, R., \& Pojanapunya, P. (2009). Implicit attitudes towards native and non-native speaker teachers. System, 37(1), 23-33.

[35] Whitty, G. (2000). Teacher professionalism in new times. Journal of In-Service Education, 26(2), 281-295.

[36] Zeichner, K. (2010). Competition, economic rationalization, increased surveillance, and attacks on diversity $\square$ : Neo-liberalism and the transformation of teacher education in the U. S. Teaching and Teacher Education, 26, 1544-1552. http://doi.org/10.1016/j.tate.2010.06.004Oslo Corpus of Tagged Norwegian Texts (no date). http://www.tekstlab.uio.no/norsk/bokmaal/english.html (accessed 29/2/2008).

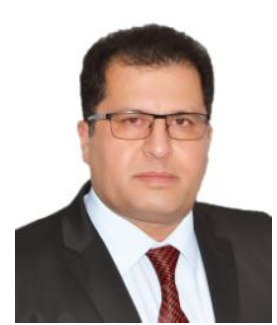

Hamid Ali Khan Eusafzai is a TESOL practitioner. He is also a doctoral student at the University of Exeter, UK. He has nearly two decades of English language teaching experience. Previously, he has taught in Pakistan and Saudi Arabia. Currently, he is an ESL faculty member at the University of Central Asia in Kyrgyz Republic. Hamid's research interests include individual differences, teachers' development, internationalization of higher education, English as a medium of instruction, and post-method pedagogy. His email is eusafzai.h@gmail.com. 